\title{
Boko Haram Activities: A Major Set Back to Nigerian Economic Growth.
}

\author{
Odita Anthony Ogomegbunam, Akan David \\ Lucturer 1 Department Of Accounting, Banking \& Finance Faculty Of Management Sciences Delta State \\ University Asaba \\ Assistant Lecturer Department Of Accounting, Banking \& Finance Faculty Of Management Sciences \\ Delta State University Asaba
}

\begin{abstract}
Wide scale violence and insurgencies are particularly disturbing because they directly impact negatively on the process of economic growth and affects adversely the levels of economic activities and productivity of a country. The study examines the effects of the recent wave of insurgencies created by the Boko Harem sect in Nigeria. The paper, thus, explores the Boko Haram menace and their implications on the nation's stability. Findings are concieved as impacts of the Boko Harem insurgence on the economic lives of Nigerian people. The paper recommends among others the need for government to improve on the state of security with all machineries at her disposal that will help identify, unravel, forestall and prosecute Boko Harem insurgents.

Keywords: Boko Harem, Boko Harem insurgencies, Boko Harem sect, Economic activities, Economy growth.
\end{abstract}

\section{Introduction}

Not less than 250 persons have so far been reported dead in the January 20, 2012 bomb attacks in Kano and obvious indications are that every attempt for peace to rein in the Islamic fundamentalists are inadequate or ineffectual, or both. According to reports, multiple explosives went off one after the other in Kano, in the usual manners of similar attacks by the members of Boko Haram sect in Maiduguri, Damaturu, Potiskum, Gombe, Abuja, and Madalla in Niger State.

It is axiomatic to posit that there is a large consensus of opinion that government must find a quick-fix solution to the problem, and then a lasting solution. This is because there is no way government will continue to spend the huge chunk of money it had been spending on security without providing security to Nigerians. Some Nigerians and groups have been so incensed with the rising insecurity in the polity that they are calling for Jonathan's resignation. There is also the belief that such calls will continue to rise until there is remarkable improvement in the maintenance of security in the land, as there is a rising impatience among the populace. If a quick action is not taken on this matter, other sect could rise making it impracticable to make peace any longer.

The dangerous trend in insecurity came with Boko Haram, the Muslim fundamentalist sect, bombing everything within reach. It had no qualms bombing innocent people, even women and children who had no inkling of what it is fighting about.

It is also clear that, the activities of Boko Haram have affected the postings of students of Southern extraction on national youth service to the north. Parents are strongly resisting the posting of their children as corpers to the north. This, in itself is a fatal blow to the noble objective of the scheme as a unifying strategy.

The Presidential assurances so far is not assuring at all; because all that Nigerians see are deadlier attacks by Boko Haram after the president had assumed that perpetrators of previous attacks would be apprehended and prosecuted. It does the government no credit to learn that arrested members of the sect escaped or set freed by the challenges and the best the President will do is throw his hands up in frustration, lamenting that the sect has infiltrated even his security agencies. It is against this background this paper seeks to address the challenges Boko Haram is posing to our National security and by extention on the economy and ways of containing their siege on the polity. To attain this objective, the paper addresses conceptual issues, explores the Boko Haram menace and their implications on the nation's stability. It finally examines the way forward and thereafter concluded.

\section{BRIEF INSIGHT TO THE HISTORY BOKO HARAM}

\section{Literature Review}

The official name of the sect is Jama'atu Ahlis Sunna Lidda-awati Wal-Jihad which can be translated as "people committed to the propagation of the prophet's teachings and Jihad". "Boko Haram" is the local dubbing of the sect by residents of Maiduguri, when it was formed in 2002. Boko Haram according to the local Hausa language simply translates to "Western education is a sin. The resident gave the group this name because of its strong aversion to western education, which it viewed as corrupting Muslims. The term "Boko Haram" is a 
derivative of the Hausa word boko, which means "Animist, western or otherwise non-Islamic education," while haram is a word with Arabic origin that figuratively means "sin".

History according to Wikipedia has it that, the group is said to have been in existence right from the 1960s but only started to draw attention in 2002. Ustaz Mohammed Yusuf is said to have assumed the leadership of the group in that year. In 2004, the group moved to Kanamma in Yobe State where a base was established and named "Afghanistan", from which attacks were launched at nearby police outposts and several police officers killed. Its leader, Yusuf, was very hostile to democracy and the secular educational system. He vowed then that the war, which is yet to start, would continue for a long time if the political and educational system are not altered or changed.

The believe of the SECT is contrast to modern findings. For example, accordin to Wikipedia, 2009 British Broadcasting Corporation (BBC, 2009) interview granted by Yusuf, who is believed to be the leader of the group. In the said interview, Yusuf declared that the belief that the world is spherical in shape is a sharp contradiction to Islamic thought and therefore should be rejected along with Darwinism and the theory that rain comes from water evaporated by the sun.

The Boko Haram sect are influenced and indoctrinated by the Koranic phrase that says "Anyone who is not governed by what Allah has revealed is among the transgressors." Boko Haram promotes the version of Islam that makes it "haram", or forbidden, for Muslims to participate in any political or social activity associated with western society. This activities that are "forbidden" or "haram" includes voting in elections, wearing shirts and trousers or receiving secular education. To Boko Haram, the Nigerian state is run by non-believers other wise referred to as "Infidel", even when the country had a Muslim president. Since the Sokoto caliphate that ruled parts of what is now northern Nigeria, Niger and Southern Cameroon, fell under British control in 1903, there has been a strong resistance among the Muslims in the area to western education. Several Muslim families still refuse to send their children to government - run "Western schools", and the problem is compounded by the ruling elites which does not see education as a priority. It is as a result of this that the Muslim cleric, Mohammed Yusuf, formed Boko Haram in Maiduguri, 2002. He established a religious complex that included a mosque and an Islamic school. Many poor Muslim families from across Nigeria and neighbouring countries enrolled their children in the school. Boko Haram is not only interested in education. The political goal is to create an Islamic state, and the school has been a recruiting ground and centre for Jihads to fight the state.

\section{BOKO HARAM: THEIR MODUS OPERANDI AND LITANY OF ATTACKS}

We posit that brief explanation of the mode of operation of the Boko Haram and a carefully selected history of their numerous attacks will help us know the significance of this topic and why a quick intervention is highly necessary.

The first obvious attack linked to the Boko Haram group was the clash with the Nigerian Police in July, 2009. This was when the Nigerian Police started investigating the group, which was engineered by reports that the group was arming itself. Several leaders were arrested in Bauchi and this led to deadly clashes with security agencies in Nigeria that resulted in the death of about 800 people. Before these clashes, several Muslims leaders and at least one military official had warned the authorities about Boko Haram. The warnings were reportedly ignored.

Also, in the same 2009, the police clamped down on sect members who were ignoring a law requiring motorcyclists to wear helmets. That lead to a furious backlash. Police stations and government offices in Borno were burned to the ground, and hundreds of criminals released in a prison break, as the violence spread across northern Nigeria. There was a counter reaction by the government and army leading to the capture and eventual death of Yusuf in police custody. Five days of fighting left some 800 people dead.

Boko Haram leaders still cite Yusuf's death as one of the main factors driving the insurgency. The group remains fiercely anti government and anti authority and resentful of the decades of corrupt, poor governance that have impoverished its home region.

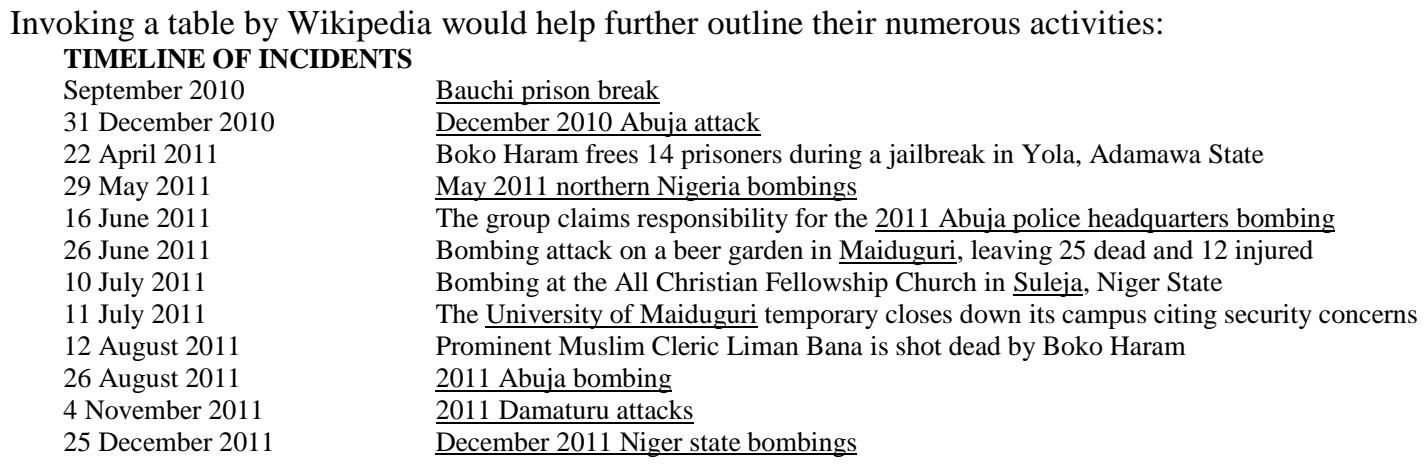


5-6 January 2012

20 January 2012

28 January 2012

8 February 2012

16 February 2012

8 March 2012

31 May 2012

3 June 2012

17 June 2012

17 June 2012
January 2012 Niger state attacks

January 2012 Kano bombings

Nigerian army says it killed 11 Boko Haram insurgents

Boko Haram claims responsibility for a suicide bombing at the army headquarters in Kaduna. Another prison break staged in central Nigeria; 119 prisoners are released, one warden killed. During a British hostage rescue attempt to free Italian engineer Franco Lamolinara and Briton Christopher McManus, abducted in 2011 by a splinter group Boko Haram, both hostages were killed.

During a Joint Task Force raid on a Boko Haram den, it was reported that 5 sect members and a German hostage were killed.

15 church-goers were killed and several injured in a church bombing in Bauchi state. Boko Haram claimed responsibility through spokesperson Abu Qaqa.

Suicide bombers strike three churches in Kaduna State. At least 50 people were killed.

130 bodies was found in Plateau State. It is presumed they were killed by Boko Haram members

\section{NEED/IMPORTANCE OF THE STUDY}

The study will help expose the magnitude of the insurgencies created, harnessed and inflicted on the national economy by the activities of the sect Boko Haram. The study will also provide government with policy insight as to the implications of the proposed options of dialogue and amnesty considerations and lastly the study will provide platform of possible pieces of advice for curtailing the menace of the Boko Haram sect.

\section{STATEMENT OF PROBLEM}

Indeed, the unity of Nigeria is seriously threatened by Boko Haram. However, the reality of this threat is worsen and manifested in the statements credited to some well placed northern Nigerians that no military action should be taken against the group. Rather than condemn this crime of Boko Haram against the Nigerian state and her people, these Northern Nigerians of Islamic faith are demanding for dialogue and amnesty for this fundamentalist sect. The question therefore is, is it right and proper to dialogue and grant amnesty to criminals that have declared war against the Nigerian state and the people? What purpose will dialogue and amnesty serve? What are the implications if government succumbs to this demand? Will this measure strengthen our national security? What impacts will dialogue and eventual amnesty have on Nigeria?

\section{OBJECTIVES}

In the light of the specified statement of problem, our study aimed at

1. To examine and address the challenges Boko Haram is posing to our Nation .

2. To evaluate the extent of its effect on the economy.

3. To assess the implications and purpose of the proposed dialogue and amnesty initiates of government.

4. To proffer possible solutions to the menace posed by the activities of Boko Haram in the economy.

\section{IS NEGOTIATION THE ANSWER?}

\section{Discussion}

According to the President of the Christian Association of Nigeria, Pastor Ayo Oritsejafor, on the $22^{\text {nd }}$ of August 2012, He strongly advised the President of Nigeria not to go into any negotiation with the Boko Haram sect. He referred as unfortunate, a statement allegedly credited to the Minister of State for Foreign Affairs, Alhaji Nurudeen Muhammed, that Nigeria was the most populated Islamic nation in the world.

Furthermore, sighting the words of Philippe de Pontet (2012), an African analyst at the Eurasia Group, posits that Boko Haram's main aim appears to be humiliating Jonathan's government, tapping into an existing sense of grievance among Muslims in the north. He and other analysts say the government's heavy-handed response has played into Boko Haram's hands (Thomas and Kujenya, 2011:12).

"The impulse is to hit back hard and there are political pressures for a crackdown," de Pontet argues, "but Jonathan is so weak in the north that he needs to be careful not to alienate people there further" (Lister, 2012:14).

The ideology that Negotiation and probably amnesty will bring back peace is quite disappointing. It's gradually becoming a norm for the Nigerian Government to negotiate with terrorist no matter the number of souls that were killed during their exploits. Not quite long the government pulled through (that is if they have actually pulled through) the Niger - Delta saga, the same Government has settled for negotiation with a group that has brought so much sorrows to Nigerians. One could imaging the $25^{\text {th }}$ of December and $1^{\text {st }}$ of January, humans roasted like goat, instead of talking about justice, we are talking about negotiation. The implication therefore is, "every man for himself, don't die because you could be used as a bait to initiate a negotiation process".

How can an economy grow with such an unsecured environment. The Yoruba Unity Forum (YUF) BBCnews(2011), the umbrella body for all Yoruba sons and daughters, is trying to do something about the 
insecurity in the environment, knowing the implications. They moved against possible incursion of the dreaded Boko Haram sect into the South-West region of the country in its general meeting, on Thursday the 23rd, 2012, at the Efunyela Hall, in Ikenne-Remo, Ogun State.

It's even more painful to know that some of the Governors in the North has put Boko Haram in their pay roll. According to report, in major newspapers recently, which was culled from an online publication, 247 ureports.com, a senior official of Boko Haram allegedly granted an interview detailing how the sect had been on the payroll of a few governors of the North. The unnamed official had claimed that the stoppage of the financial support by the new government in Kano had warranted the massive bomb attacks on the state. "Most of them pay us monthly to leave their state alone," he was quoted to have said.

In clear terms, Negotiation is not and can never be the answer to the solution of the crises of Boko Haram. Man is dynamic and as such ought to learn from past mistakes and not to repeat them. There is a popular saying that "it's only a mad man that does the same thing and expects a different result". The amnesty granted the Militants of the Niger Delta has not truly ended the crises. Huge amount are still been paid to the same group to guide the oil pipe lines, yet their nefarious activities has not ended.

\section{FINDINGS.}

Findings from the study are reflective of the apparent impacts of the insurgencies on the Nation as related below.

\section{THE IMPACT OF BOKO HARAM ACTIVITIES ON THE ECONOMY}

Boko Haram's activity in the Northern states of the country has disrupted Economic activities to no small extent. Their activities in Kano, Kaduna, Bornu, Yobe and Bauchi is gradually changing the economic structure of the whole of northern Nigeria. Research by the Businessday newspaper indicates that if the violence persists, development in that region will be tampered and the gap between the North and other regions will widen further (BDN 2012).

The evidence and fast changing indices (in form of changing migration patterns, cost of insurance in the North, mass repatriation of funds, dearth in skilled labour etc) speaks volumes. In economic terms, what the insurrection created is a systemic distortion of existing economic patterns and structure in the Northern region.

It's a clear fact that each region in Nigeria compliments the other. What the North lacks in access to the sea, the south provides. The North wields 78 percent of Nigeria's land which supports most of Nigeria's agriculture (food, cash crops and livestock). The south-west's terrain supports both domestic and international commerce and provides an import/export rout. While the South-South and some parts of the South-East wield Nigeria's oil wealth. If Boko Haram's activities persist, this economic symphony will be altered significantly.

\section{Increase in Migration}

The increased intensity of bombings in the north necessitated a strategic mass movement of individuals from the most affected northern states especially in early 2012. This was accentuated by the uncertainties surrounding the fuel price crisis at the time. The movements were of a strange kind since both southerners and Northerners simultaneously moved from Boko Haram strong holds. While Northerners moved from the south-East in hundreds many relocated either to safe parts of the North or the South-West. Migrating Southerners were mostly women and children (moving to the South-East) who were sent away to safety by their husbands. The men, mostly businessmen stayed behind to defend their livelihood.

More people are still migrating and those that left are refusing to go back. There is no doubt that if the crisis persists, there will be significant dearth in professionals, artisans and commercial professionals in the region. Evidence shows that many professionals in the service sector and doctors have sort for transfer out of affected zones in the North ( AllAfrica,2012; BBCnews, 2012). Some whose requests are not being honored and feel they cannot continue in the apprehension resigned on the back of pressure from relations. Those who remain do so because opportunities are few. One preliminary indication of the developing lacuna is that most vacancy announcements from the North (especially late last year) carried salaries; perhaps in an attempt to attract qualified individuals.

Rent in the North

Rent in major metropolises in Kano, Bornu and Yobe reduced significantly as the crisis accelerated ( Cocks, 2012) . This is normal as population depletes. But the situation is expected to be different in regions where forced migrants flee to.

The Roads are Less Busy.

One of the most affected sectors of the Northern economy is transport. The effect of Boko Haram is felt more by 
those involved in the transportation of passengers from the South to the North and vice versa. Whether it is the 13 -seater passenger bus operator or the 59-passenger luxury bus operator, the woes cut across.

Before the onslaught, most operators made at least two trips per week, on their vehicles. But at the moment, they hardly make one trip per week. Indeed, the level of activity in road transport has reduced abysmally. As of now, it requires twice as much effort to get a 13 -seater bus full of passengers these days. Clearly, fewer individuals are travelling northward.

Markets are Scanty

People only go to the market when its necessary and the free flow of activities is gradually becoming history. How will business men and women make ends meet.

\section{Demand by The Boko Haram}

In most northern cities, the most heavily guarded places are the police stations and military formations (BBC, 2011). There are no soldiers or policemen on most streets, so people in those areas are at the mercy of violent people. The issue of dialogue is a very controversial one, because people view it from different perspective. While those that are experiencing the bombings and killings feels that military might of government would get down the Boko Haram, while those living far from north feel negotiation is weakness on the part of the government. It appears the Government has so far not proven her worth in this issue. Consequent to the fact that it appears every man is on his own in this case. Others feel that negotiation might be a good option but it can't be done without a sincerity of purpose from both sides. We have a lot of people benefiting from this carnage; there are security contractors and defence entrepreneurs. Security votes are spent in the name of ensuring security by the states and federal government. And even in the 2012 budget, about 25 per cent of the resources that ought to have gone to health, education and infrastructure has been diverted to security. This is the problem. So much money has been spent, yet the insurgents have not been defeated. You don't expect a government that is not sincere to achieve peace. I believe this could be one of the reasons it has been difficult all this while to achieve a ceasefire.

However, the big question is, what is their major demand? "That the President should convert to Muslim and that the nation be governed by Sharia Law". Freedom of worship is allowed even in most muslim nations. This automatically makes their demand non negotiable.

A government that can not protect her citizenry should simply resign and leave the sit for a stronger, more considerate and sincere government. In our own opinion, we do not think the people of Nigeria need a President that could only increase fuel on the first of January after a brutal bomb explosion that took place on the $25^{\text {th }}$ of December, the previous year. So much money is being spent on security that obviously do not exist.

\section{Recommendations/Suggestions}

In the light of the above sections on discussion and findings we here by recommend that:

- An urgent frantic solution devoid of any kind of bias be taken.

- The President should point out the sponsors of the Boko Haram who are members of his cabinet. As he rightly told the good people of this country that he knows them.

- There should be an investigating committee, comprising of top and experienced military personnel whose duty should be to find out if this whole saga is political or religious and what is the intension of the pioneers.

- Cases of violence should be taken seriously, the consequence should be nothing less than DEATH to the perpetrators. This include kidnapping, armed robbery and the likes.

- Government should plant security personnel in virtually every areas in the states (especially the northern states) that are prone to attacks by these insurgents. This could forestall the ability to group and regroup by Boko Haram members to launch an attack.

- Every citizen should be sensitized on the need to be security conscious. People should be apt to report to the police any suspicious movement or strange actions in their localities.

- Giving money to the same Niger - Delta people you granted amnesty to guide the oil pipelines is ridiculous. So much money is spent in that direction yet they say PETROLEUM PRODUCTS must increase. We suggest that every unnecessary expenses in the name of settling insurgents, branded negotiations should stop .

- Employment should be a major agenda of government. Qualified people should be employed in order to avoid a pool of unemployed individuals as ready and easy recruits for the nefarious activities of the Boko Haram sect. 


\section{Conclusions}

It can be concluded without using any empirical analysis, that the activities of the Boko Haram is a major deterrent to the economic development in Nigeria which by extension affects the productive system of the nation. A nation under this controversial circumstance need a leader that has the people at heart. The well being of the people should be on the top most list of his agenda. Policy actions of government must ensure that the productive efforts of its citizenry is maximized, which is only attainable in an atmosphere of peace. Thus all necessary suggestions, recommendations, advice and machinery that a government must be in place for the attainment of the objective of peace must be done. This same philosophy goes for the sovereign state, Nigeria.

\section{LIMITATIONS}

One of the major limitations encountered in the study is the challenge of establishing quantitative measures of the violence and disorders created by the Boko Harem insurgency, which therefore relegated the present study to a qualitative output.

Another limitation of the study is the availability of data, that is data constraint. Being a grey area and borne out of recent experience of Nigeria, not much have been written on this. And of course since it is recent, barely 2 to 3 years, these short years do not permit an in-depth analysis of effects.

\section{SCOPE FOR FURTHER RESEARCH}

The study basically is a qualitative work on the effects of the activities of Boko Harem on Nigerian economy. It therefore follows that the study does not provide for quantitative impact assessment of the insurgency on the economic state of Nigeria. Future study needs to explore the possibility of quantitative measures of these effects of Boko Harem on productivity in the Nigerian economy.

Online Resources

\section{References}

[1]. AllAfrica. (2012) "Nigeria: Kidnapped German, Six Gunmen Killed as JTF Invades Boko Haram's Den". http://allafrica.com/stories/2016010222. Retrieved 2012 - 6- 26

[2]. Ayo (2012), "Boko Haram issues three-day ultimatum to christians". The Vanguard http://en.wikipedia.org/wiki/Boko Haram Retrieved 14 March 2012.

[3]. BBC News (2009) "Nigeria's 'Taliban' enigma".. http://news.bbc.co.uk/2/low/Africa/8172270.stm Retrieved 2011-07-28

[4]. - ------ (2011) "Nigeria Boko Haram attack 'kills 63' in Damaturu". http://www.bbc.co.uk/news/world-africa-14677957. Retrieved 2011-11-05.

[5]. - ------ (2011) "Nigeria churches hit by blasts during Christmas prayers". http://www.bbc.co.uk/news/word-africa/16328940. Retrieved 25 December 2011.

[6]. - ------- (2012) "Nigeria: Boko Haram claims Kaduna army suicide attack". http://www.bbc.co.uk/news/word-africa/16942694. Retrieved February 8, 2012.

[7]. Cocks, Tim (2012). "Nigeria army says kills 11 Boko Haram insurgents". Reuters. http://www.reuters.com/article/2012/01/28/ . Retrieved February 27, 2012

[8]. Lister, F.(2012) "Christians flee attacks in northeast Nigeria". http://www.trust.org/alertnet/news/christains-flee-attack-in-northeastnigeria/. Retrieved 7 January 2012.

[9]. Philippe D. P. (2012) "BREAKING NEWS: Boko haram claims responsibility for Kano attacks". http://dailytrust.com.ng/index.php . Retrieved 20 January 2012.

[10]. Thomas, S. and Kujenya, J. (2011) "Nigeria: Boko Haram Suicide Attack Killed Dozens". The Huffington Post. http://www.huffingtonpost.com/2011/11/05 Retrieved 2011-12-25.

Newspaper

[11]. BDN ( 2012), "Business Day Staff: boko haram: what cost for the northern economy" Business Day, Lagos, Wednesday, $18^{\text {th }}$ April, 2012. 